\title{
皮膚科から見た掌蹠膿疮症と扁桃病巣感染症
}

\author{
藤原 啓次 ${ }^{1)} \cdot$ 山本 良一2) ・林 泰弘 ${ }^{3)} \cdot$ 山中 昇 ${ }^{3)}$
}

\section{Pustulosis Palmaris et Plantaris and Tonsillar Focal Infection; A Report of Questionnaires to Dermatologists}

\author{
Keiji Fujihara \\ (Wakayama Rousai Hospital) \\ Yoshikazu Yamamoto \\ (Saiseikai Wakayama Hospital) \\ Yasuhiro Hayashi and Noboru Yamanaka \\ (Wakayama Medical College)
}

\begin{abstract}
It is widely accepted by otolaryngologists in Japan that the palatine tonsil is typically the site of focal infection in cases of pustulosis palmaris et plantaris (PPP). Numerous reports have indicated that about $80 \%$ of PPP cases are successfully treated by tonsillectomy. It is thus important to know how dermatologists treat PPP patients, especially in investigations of focal infection. Questionnaires were sent to 577 dermatologists in the Kinki district and 238 answers were analyzed. Dermatologists tended to treat PPP patients first with corticosteroid ointment and secondly with tonsillectomy. However the questionnaires revealed that tonsillectomy was performed on an average of 1.5 patients per year as treatment for PPP. Examination of focal infection, was carried out by about $70 \%$ of the dermatologists only in severe cases. Regarding the pathogenesis of PPP, $97 \%$ of the dermatologists agreed that PPP may be the result of tonsillar focal infection. However, almost all of them indicated that the percentage of patients in which the tonsil plays a role in the pathogenesis of PPP is less than 50\%. The majority of dermatologists seem to feel that tonsillar focal infection plays a small part in the pathogenesis of PPP. On the basis of this study, it is stressed that we as otolaryngologists, should more clearly communicate the role of focal infections in dermatological disorders such as PPP and educate dermatologists regarding the very high curative rate of PPP by tonsillectomy.
\end{abstract}

Key words : pustulosis palmaris et plantaris, tonsils, focal infection, questionnaires to deramatologists

はじめに

病巣感染症は紀元前の時代から知られてはいたが, 病 巣感染として体系つけりられたは20世紀に入ってからで ある. Gutzeitらは「身体のどこかに限局した慢性の感 染性炎症病巣(原病巣)があり, それ自体は汪とんど無症
状であるかまたは時に軽微な症状を呈しているにすぎな いのに, 原病巣から離れた諸藏器に反応性の器質的ある いは機能的障害 (二次疾患)を起こすもの」と定義した ${ }^{11)}$. 扁桃と皮膚疾患との関連性については，1920年頃より報 告されるようになった，本邦でも耳鼻咽喉科，皮膚科か

1) 和歌山労災病院耳鼻咽喉科

2）和歌山済生会病院耳鼻咽喉科

3）和歌山県立医科大学耳鼻咽喉科学教室 
ら症例報告が多くなされてきた．野田ら2) は全国大学皮 膚科学教室へのアンケート調査に上り, 病巣感染症の可 能性のある疾患は40疾患であるとし, 掌蹠膿疮症 (pustulosis palmaris et plantaris) は皮膚疾患の中で最も病 巣感染症の可能性が高いとしたが, 実際には病巣除去は あまり行われていないといら現状についても報告してい る. 形浦 ${ }^{3)}$, 小島 $5^{4)}$, 山本ら ${ }^{5)}$, (掌蹠膿疮症患者の扁 摘効果について，多数例を集めて検討し，注ぼ70〜90\% であると報告している。また，小野ら ${ }^{6)}$ は扁摘群で83.6
\%, 非扁摘群で39.2\%，林ら ${ }^{7}$ は扁摘群で $85.9 \%$, 非扁 摘群では $80.5 \%$ と保存療法に比べても, 扁摘効果が高い ことを報告している。このような結果を踏をえて，現在 では皮膚科医が掌蹠膿疱症を含め, 病巣感染症の可能性 のある皮痛疾患についてどのように考光，対処している かを知るためアンケートによる調查を行った。我々は特 に, 実地臨床の場にある病院の皮膚科勤務医と開業医を 対象とした。

\title{
掌蹠膿疮症と病巣感染症に関するアンケート調査
}

1. 扁桃病巣感染症の可能性のあるものとして、ぞのような皮膚疾患をお考えですか? 以下の中よりお選び下さい。また、その他の疾患についてもお考えの場合、その他の項 にお書き下さい。

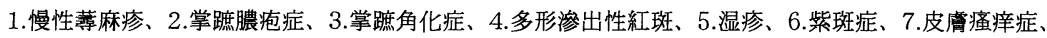

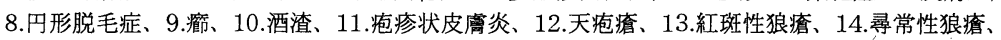

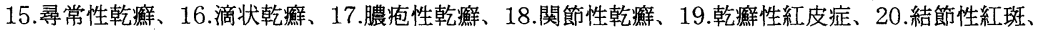
21 . 紅色苔痽、22.尋常性痤餈、23.血管神経性浮腫、24. 帯状栬疹、25.㾕疹、26.膿皮症、 27.その他（

2.掌蹠膿疮症について有効と考えている治療法を 3 つお選び下さい

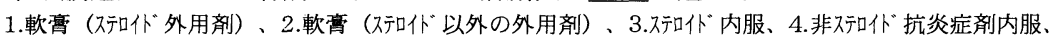

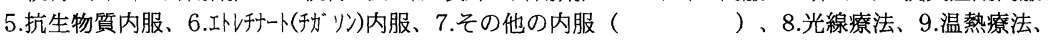
10. 扁桃摘出術、11. 歯科的治療、12.その他の病巣除去 13.その他（

3.最も有効とお考えの治療法は

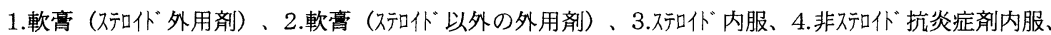

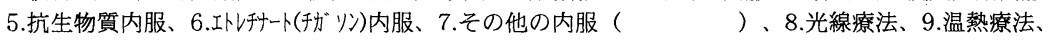
10.扁桃摘出術、11.歯科的治療、12.その他の病巣除去（ 13.その他（ ）、8.光線療法、

4.掌蹠膿疮症患者の来院時の取り扱い状況について1つお選び下さい 1.自院での夕治療を行う、2.難治例について病巣検索を行う（耳鼻咽喉科、歯科、他科（）へ紹介 する）、3.はじめから病巣検索を行う（耳鼻咽喉科、歯科、他科（）へ紹介する）、 4.その他（

5.掌蹠膿疮症に対して扁桃誘発試験を行いますか 1.全例に行う、2.ほとんどの症例に行う、3.50\%以上、4.50\%未満、5.ほとんど行わない、6.全く行わな い、7.その他（

6.誘発試験時に最も重視する項目は 1. 白血球数、2.体温、3.赤沈、4. 皮疹の増悪、5.その他（

7.掌蹠膿疮症発症に関して扁桃の関与が考えられる症例の割合は? 1 つお選び下さい 1.全例に関与している、2.ほとんどの症例に関与している、3.50\%以上、4. $50 \%$ 未満、 5. .とんど関与 していない、6.全例に関与していない、7.その他（

8. 平成 9 年度の 1 年間で掌蹠膿疮症の治療として扁桃摘出をされた例はありますか
1.あり（約
例)、2.なし（約
例)、3.その他（

\author{
)
}

9.掌蹠膿疮症の治療として扁桃摘出をされた例（ 1 年以上の経過例）について、扁桃摘出 効果があると考えている症例の割合について 1.全例に効果がある、2.ほとんどの症例に効果がある、3. $50 \%$ 以上、4. $50 \%$ 未満、 5. ほとんどの症例に 効果はない、6.全例に効果はない、7.その他（

10.掌蹠膿疮症の治療として扁桃摘出に関してご意見・ご感想をお聞かせ下さい 
対象と方法

対象は日本皮膚科学会大阪地方会の会員で，医育機関 以外の病院勤務医々皮膚科開業医577名(開業医388名, 病院勤務医189名)に対して郵送によりアンケート調査を 行った．有効回答を得たのは238名(41.2\%)（うち開業医 178名 (45.9\%)，病院勤務医60名 (31.7\%))であった．設 問は病巣感染症に関するもので，内容は，病巣感染症と 考兄る皮膚疾患, 有効之考兄ている治療法, 掌蹠膿疮症 患者来院時の取り扱い状況，扁桃誘発試験の実施の有無 と重視項目, 掌蹠膿疱症の発症への扁桃の関与, 扁摘実 施の有無々効果，扁桃摘出に関する意見・感想について 行った(図 1).

\section{結果}

1 ) 病巣感染症と考吕る皮膚疾患

野田ら 2) がアンケート調查で報告した26皮膚疾患を挙 げ，それを選んでもらい(複数回答可)，それ以外の疾患 名をその他の疾患の項目に記入するよう依頼した。表 1 に示寸ように掌蹠膿疮症は230名, 多形滲出性紅斑135名, 結節性紅斑117名，慢性薵麻疹114名が注淁半数の医師で 病巣感染の可能性を指摘した。 以下, 多い順に滴状乾癄, 紫斑症, 膿疮性乾痽, 尋常性乾癄, 関節性乾癄, 湿疹が 10位までの結果であった。これは開業医，勤務医で汪と んぞ順位の変化は認められなかった．1 人でも指摘した 疾患を加えると，31疾患が認められた。これを表 2 で各 疾患群に分けてみた。

\section{2 ）有効と考えている治療法}

掌蹠膿疮症に関して有効と考兵ている治療法について， 12の選択肢とその他から 3 つを選択するよう依頼した． 表 3 のように 9 割の皮膚科医がステロイド外用剤を選ん でいたが， 2 位は扁桃摘出であった. 有効と考学ている

\section{表 1 病巣感染症と考光る皮膚疾患(複数回答)}
1. 掌蹠膿疮症
2. 多形滲出性紅斑
3. 結節性紅斑
4. 慢性萇麻疹
5. 滴状乾癖
6. 紫斑症
7. 膿疮性乾痽
8. 尋常性乾颜
9. 関節性乾㿏
10. 湿 疹

230名 $(97 \%)$

135名 (57\%)

117名 (49\%)

114名 (48\%)
75名 $(32 \%)$

66名 (28\%)

59 名 $(25 \%)$

34名 (14\%)

33名 $(14 \%)$

25名 $(11 \%)$
表 2 疾患群に分けた病巣感染症と考兄る皮膚疾患

1. 膿皮症群
a ）掌蹠膿疮症
b ) 癭腫症
c ）細菌性膿疮

2. 薵麻疹群
a ）慢性薵麻疹
b ）急性薵麻疹
c ）血管神経性浮腫
d) 痒 疹
a）多形滲出性紅斑
135名 $(56.7 \%)$
b ）結節性紅斑
117名（49.2\%）

230名（96.6\%）

3名 ( $1.3 \%)$

1名（ $0.4 \%)$

3. 紅斑群

4. 角化症群
a）尋常性乾痽
34名 (14.3\%)
b ) 滴状乾痽
75名 $(31.5 \%)$
c ）膿疮性乾摩
59名 (24.8\%)
d）関節性乾痽
33名 (13.9\%)
e）掌蹠角化症
f ）ジベルバラ色粃糠疹
9名 ( $3.8 \%)$
1名 ( $0.4 \%)$

5. 血管系皮膚疾患群
a ) 紫斑症
66名 $(27.7 \%)$
b ）薵麻疹様血管炎
1名 $(0.4 \%)$

6. 膠原病群
a ）紅斑性狼瘡
5名 ( $2.1 \%)$

7. 湿疹群
a ) 湿 疹
b ）貨幣状湿疹
25名 $(10.5 \%)$
c ）撒布疹
1名 ( $0.4 \%)$
d）皮膚瘦痒症
1名 (0.4\%)
e）アトピー性皮膚炎
12名（5.0\%)
3名（1.3\%)

8. 脱毛症群
a ）円形脱毛症
12名（ $5.0 \%)$

9. 細菌疹群
a）.膿皮症
b）尋常性狼瘡
16名（6.7\%）
1名（0.4\%)

10. 水疮症群
a ）疱疹状皮膚炎
4名（1.7\%
b ）天疱瘡
3名 ( $1.3 \%)$

11. 紅皮症群
a ）乾癄性紅皮症
16名（ $6.7 \%)$
b ）中毒疹
1名 ( $0.4 \%)$

12. 脂腺疾患群
a ）尋常性痤瘡
2名（ $0.8 \%)$

治療法を 1 つだけ選んだ結果を表 4 と示した. 表 4 の結 果は表 3 と核涪同じで，扁桃摘出は 2 位であった．治療 法の結果は開業医，勤務医でほとんど順位の変化は認め られなかった。 

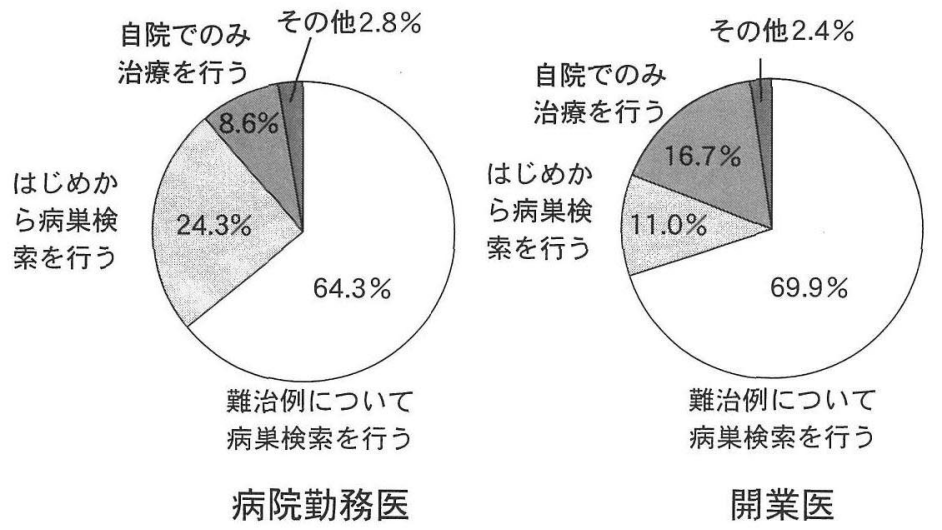

図 2 掌蹠膿疮症患者の来院時の取り扱い状況

表 3 掌蹠膿疱症に有効と考光ている治療法 ( 3 つを選択)

\begin{tabular}{lr}
\hline \hline 1. 軟膏(ステロイド外用剤) & 214 名 $(90.0 \%)$ \\
2. 扁桃摘出術 & 106 名 $(44.5 \%)$ \\
3. 抗生物質内服 & 90 名 $(37.8 \%)$ \\
4. エトレチナート (チガソン)内服 & 75 名 $(31.5 \%)$ \\
5. 光線療法 & 71 名 $(29.8 \%)$ \\
6. ステロイド内服 & 64 名 $(26.9 \%)$ \\
7. 軟膏(ステロイド以外の外用剤) & 49 名 $(20.6 \%)$ \\
8. 歯科的治療 & 47 名 $(19.7 \%)$ \\
9. その他の内服 & 23 名 $(9.7 \%)$ \\
10. 非ステロイド抗炎症剤内服 & 20 名 $(8.4 \%)$ \\
11. その他の病巣除去 & 20 名 $(8.4 \%)$ \\
12. その他 & 5 名 $(2.1 \%)$ \\
13. 温熱療法 & 1名 $(0.4 \%)$
\end{tabular}

表 4 掌蹠膿疮症に有効と考兄ている治療法 ( 1 つを選択)

\begin{tabular}{|c|c|}
\hline 1. 軟膏 (ステロイド外用剂) & 111名（46.6\%） \\
\hline 2. 扁桃摘出術 & 42名 (17.6\%) \\
\hline 3. ステロイド内服 & 26 名 (10.9\%) \\
\hline 4. エトレチナート (チガソン)内服 & 21 名（ $8.8 \%)$ \\
\hline 5. 抗生物質内服 & 12名（ $5.0 \%)$ \\
\hline 6. 光線療法 & 13 名 ( $5.5 \%)$ \\
\hline 7. 軟高 (ステロイド以外の外用剤) & 11名（ $4.6 \%)$ \\
\hline 8. その他の内服 & 11名（ $4.6 \%)$ \\
\hline 9. 歯科的治療 & 10名（ $4.2 \%)$ \\
\hline 10. その他の病巣除去 & 6 名（2.5\%) \\
\hline 11. 非ステロイド抗炎症剤内服 & 3名 (1.3\%) \\
\hline 12. その他 & 2名 $(0.8 \%)$ \\
\hline 13. 温熱療法 & 0名（ $0 \%)$ \\
\hline
\end{tabular}

3）掌蹠膿疱症患者来院時の取り扱い状況

掌蹠膿疱症患者来院時に「自院でのみ治療を行ら」,「難
治例について病巣検索を行ら」,「はじめから病巣検索を 行ら」以上の 3 つの選択肢と「その他」から選えでもら った。病院勤務医，開業医ともに最も多かったのが「難 治例について病巣検索を行う」で，それぞれ64.3\%， 69.9\%で過半数を占めていた(図 2 ).

4 ）扁桃誘発試験の実施の有無と重視項目

扁桃誘発試験の実施について「全例に行う」,「臣とえ どの症例に行ら」,「50\%以上」,「50\%未満」、「ほとえ゙ 行わない」，「全く行わない」以上の 6 つの選択肢之「そ の他」から選んでもらった。病院勤務医では㐆とんど行 わないが30\%，開業医では全く行わないといらのが $48 \%$

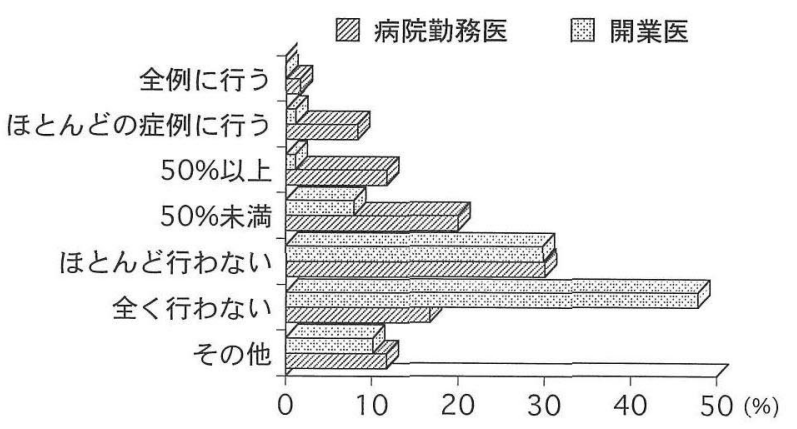

図 3 扁桃誘発試験の実施について

表 5 誘発試験時に最も重視する項目

\begin{tabular}{ll}
\hline 1. 皮疹の増覀 & 79名 $(33.2 \%)$ \\
2. 白血球数 & 26名 $(10.9 \%)$ \\
3. その他 & 5名 $(2.1 \%)$ \\
4. 赤 沈 & 1名 $(0.4 \%)$ \\
5. 体 温 & 0名 $(0 \%)$
\end{tabular}


で最も多く認められた(図 3 ). 誘発試験時に最も重視す る項目は「皮疹の増悪」であった(表 5 ).

5 ）掌蹠膿疱症の発症への扁桃の関与

掌蹠膿疮症に関して扁桃の関与が考えられる症例の割 合について「全例に関与している」,「ほとえどの症例に 関与している」，「50\%以上」，「50\%未満」，「汪とんど関 与していない」,「全例に関与していない」以上の 6 つの 選択肢と「その他」から選んでもらった。 $50 \%$ 未満とい 与回答が病院勤務医で $64.3 \%$, 開業医で $54.5 \%$ 之過半数 を占めていた(図 4 ). 平成 9 年度の 1 年間で掌蹠膿疮症 の治療として扁桃摘出をされた例について尋ねたが，実 際に扁桃手術を受けた患者数は病院勤務医の方が割合と しては33.3\%と開業医の19.7\%よりは多いが，開業医で も病院勤務医でも症例は少なく，それぞれ 1 年間に平均 1.5 例と 1.8 例と扁桃摘出の実施状況は非常に少ないとい ら結果であった(図 5 )。

6 ）虛桃摘出の効果があると考えている症例の割合 掌蹠膿疮症の治療として扁桃摘出をされた例 ( 1 年以
上の経過例)について，扁桃摘出の効果があると考えて いる症例の割合について 5 ) と同じ選択肢から選んでも らった. $50 \%$ 未満という回答が最も多く, 病院勤務医て 28.3\%，開業医で23.6\%であった(図 6).

7 ) 扁桃摘出に関する意見・感想

掌蹠膿疮症の治療として扁桃摘出汇関しての意見・感 想を求めたところ，154名に回答が得られた.内容を分 析すると,「扁摘例の大半は 1 年以内に皮疹の発現が停 止している. 最も有効な治療法である」といった扁桃摘 出に賛成の意見が36名 $(23.4 \%)$, 「扁桃摘出術はすべて の例に絶対適応となる治療ではないと考学ている」「術 後出血などのリスクがある」「痛い思いをして治らなか ったら気の毒」などの慎重に考觉るといら意見が53名 (34.4\%), 「掌蹠膿疱症は尋常性乾痽の 1 型といら考皇 を重視しており, 扁桃摘出の意義は根本的治療とは無関 係と考える」などの反対意見は 6 名 (3.9\%)，「経験がな い」は8名(5.2\%)といら結果であった. 以上より慎重 に考えるといら意見が $34.4 \%$ と最も多くみられた。また，

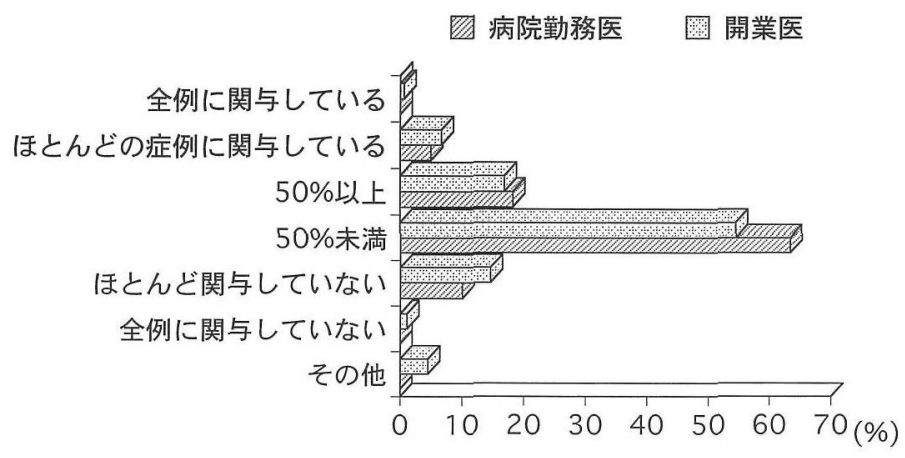

図 4 掌蹠膿疮症の発症への扁桃の関与

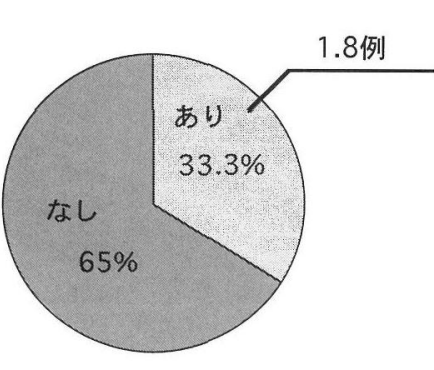

病院勤務医

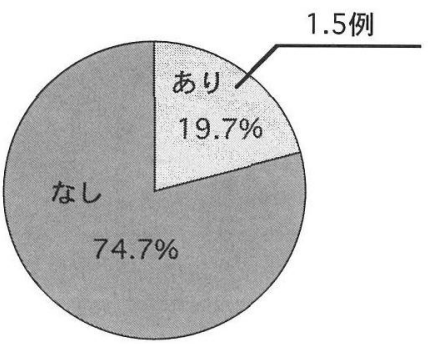

開業医

図 5 扁桃摘出例 ( 1 年間) 


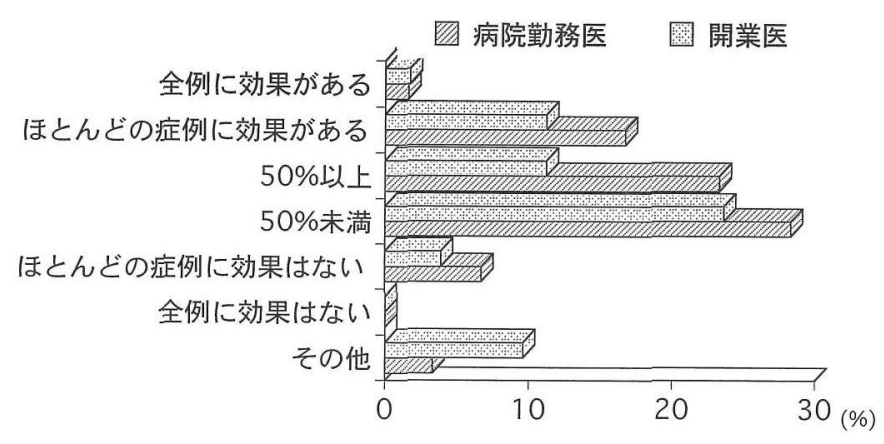

図 6 扁桃摘出の効果があると考光ている症例の割合

「病巣感染に理解のある耳鼻科医がどこに拈られるのか わからないので紹介先に悩む」「咽頭所見から耳鼻科に 紹介しているが，扁摘の適応ではないとの返事が注とん どである」といった耳鼻科側に問題があるとした意見が 27 名 $(17.5 \%) ， 「$ 良いデータが出れば，患者さんにも勧 めたいと思ら」「扁桃誘発試験の意義・実態が必ずしも 皮膚科に伝わっていないため，耳鼻科医と皮膚科医の間 に認識の差があるのでは」のように耳鼻科医と皮膚科医 の認識の差があるとした意見もみられた。他に患者側に 問題があるとした意見が 11 名 $(7.1 \%)$, 扁桃摘出後の再 発が問題とした意見が 4 名 $(2.6 \%)$ であった。上記の意 見・感想を大阪府, 兵庫県, 奈良県, 和歌山県の 4 地域 で検討した(図 7 )。賛成，慎重に考兄る，反対について は地域差を認めなかったが，奈良県で経験なしが多く， 和歌山県では耳鼻科側の問題とした意見は認められなか った。

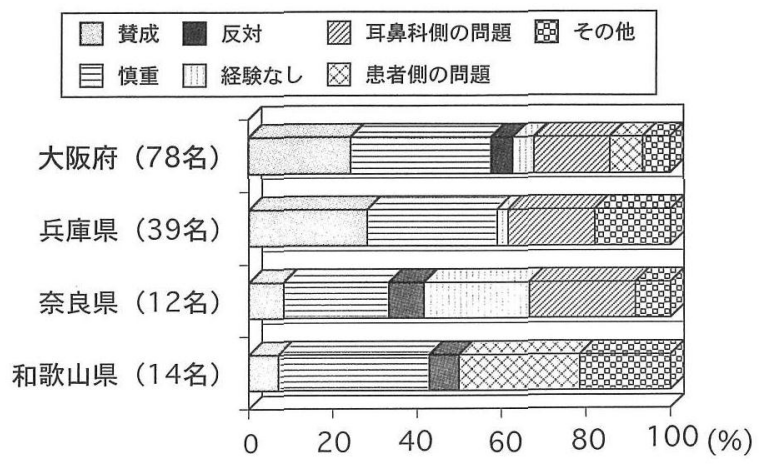

図 7 扁桃摘出に関する意見・感想の地域特性

\section{考察}

野田ら ${ }^{2)}$ が報告したように，病巣感染症と考えられる 疾患は今回の調査でも非常に多種の皮膚疾患にわたって いることが改めて判明した。中でも掌蹠膿疮症は回答を 得た皮膚科医の $97 \%$ が病巣感染症と認めて拈り，午の治 療法として扁桃摘出術は第 2 位に挙げられた。皮膚科医 に抮いても掌蹠膿疱症の病巣として扁桃が重要であると いら認識が高いことが認められた。しかし，病巣検索は 難治例のみに行うとした回答が多く，扁桃誘発試験はほ とえど実施されていなかった。掌蹠膿疮症に関して扁桃 の関与が考えられる割合は50\%未満といら回答が姫とん どであり，扁桃摘出術を依頼した症例は 1 年間に開業医 で1.5例，病院勤務医で1.8例と非常に少ないことが判明 した。病院勤務医は開業医に比べて, 病巣検索や扁桃摘 出術について耳鼻科に紹介しやすい立場にあると考光開 業医と対比して検討したが，以上の結果は勤務医でも開 業医でもほとんど差は認められず，皮膚科医全体の考光 方を表していると考昗た。病巣感染症への関心度は非常 に高いが，実施段階になると消極的姿勢が認められ，ま る種の矛盾が存在するのではないかと考光た：この一因 として皮膚科医には掌蹠膿疱症の病因は多因子に及んで おり，病巣感染だけではないので保存的治療で十分とい ら考方方が多いことが考えられた. 皮膚科学の教科書で も掌蹠膿疱症の病因として病巣感染症に関する詳しい記 載はされておらず，治療として扁桃摘出が記載されてい るのみである ${ }^{899)}$. 再発の問題から扁桃摘出術はあまり 行われていないといら記述認められた10), 耳鼻科側か ら出版した皮膚科疾患に関する書籍では病巣感染症执よ び診断について詳しく述べられている11). 今回のアン ケートでも, 病巣感染症と考学る皮膚疾患は掌蹠膿疱症 
に限らず，多岐にわたっていることから皮膚科学の教科 書でも病巣感染症の詳しい記述は必要であろう。また, 病巣検索と除去について協力的な耳鼻科医が存在しない といら皮膚科医からの意見も寄せられ，地域的な差は認 められるが非協力的な耳鼻科医も存在することから，今 後皮膚科医に限らず耳鼻科医に対しても，扁桃の病巣性 の術前診断の意義と病巣除去の有効性について啓蒙して いく必要性が認められた。

稿を終えるに当たり，このアンケート調査にご協力いただい た日本皮膚科学会大阪地方会の会員の諸先生に, 心から感謝を 申し上げます。

当論文の要旨は, 第80回耳鼻咽喉科臨床学会総会シンポジゥ ム「日常臨床に括ける病巣感染を探る一 $\mathrm{IgA}$ 腎症扣よび掌蹠 膿疮症の扁摘による効果一」に拈いて発表した.

\section{参考文献}

1) Gutzeit K and Parade GW : Fokalinfektion Eergebnisse. Inn Med u Kinderheilk $57:$ 613 722, 1939.

2 ）野田 寛, 栗田建一, 国吉雅子, 他 : 扁桃病巣感染性皮膚 疾患に関する全国大学皮虐科学教室アンケート調查報告. 臨皮 $33: 67 \sim 71,1979$.

3 ) 形浦昭克 : 扁桃病巣感染症 一発症機序の解明と臨床への 応用一. 第87回日本耳鼻咽喉科学会宿題報告モノグラフ.
6〜15頁, 1986.

4 ）小島未知郎, 松本浩司, 野田哲哉, 他: 扁桃病巣感染症に 护ける扁摘術後経過と扁桃誘発試験の評価. 日扁桃誌 25 : $217 \sim 224,1986$.

5 ) 山本真一郎, 伊藤博隆, 馬場駿吉 : 扁桃病巣感染症に拈け る術前検查と扁摘の効果. 日扁桃誌 $31: 94 \sim 98,1992$.

6 ）小野友道, 城野昌義, 江川清文, 他 : 掌蹠脤疮症に打ける 免疫学的検討ならびに扁摘の効果. 日扁桃誌 $21: 180$ 188, 1982.

7 ) 林 泰弘, 山中 昇: 病巣感染之扁桃摘出. 臨床皮膚科 $50: 143 \sim 148,1996$.

8 ) 飯塚一: 膿疮症. 皮膚科学(小川秀興, 新村眞人編). 168 171頁, 南山堂, 東京, 1998.

9 ) 大河内仁志 : 掌蹠膿疮症. 皮膚科診療ガイド(玉置邦彦, 日野治子編)。208頁, 中外医学社, 東京, 1998 .

10）塩原哲夫：掌蹠膿疮症. モダンクリニカルポイント皮膚科 (長島正治, 原田昭太郎編). 106 107頁, 金原出版, 東京, 1992.

11) 藤原啓次 : 掌蹠膿疮症. 全科でみる耳鼻咽䐅の病変(澤木 修二, 高橋宏明, 原田康夫編). $215 \sim 218$ 頁, 金芳堂, 京 都, 1998 .

$$
\begin{aligned}
& \text { 原稿受付 : 平成 } 10 \text { 年 } 8 \text { 月 } 20 \text { 日 } \\
& \text { 原稿採択: 平成 } 10 \text { 年 } 9 \text { 月 } 25 \text { 日 } \\
& \text { 別刷請求先 : 藤原啓次 } \\
& \text { 干640-8505 和歌山市古屋435 }
\end{aligned}
$$

